\title{
Survival and risk of relapse of acute lymphoblastic leukemia in a Mexican population is affected by dihydrofolate reductase gene polymorphisms
}

\author{
YAZMÍN GÓMEZ-GÓMEZ ${ }^{1 *}$, JORGE ORGANISTA-NAVA ${ }^{1 *}$, MÓNICA VIRGINIA SAAVEDRA-HERRERA ${ }^{1}$, \\ ANA BERTHA RIVERA-RAMÍREZ ${ }^{3}$, MARCO ANTONIO TERÁN-PORCAYO ${ }^{3}$, LUZ DEL CARMEN ALARCÓN-ROMERO², \\ BERENICE ILLADES-AGUIAR $^{1}$ and MARCO ANTONIO LEYVA-VÁZQUEZ ${ }^{1}$
}

\begin{abstract}
Laboratories of ${ }^{1}$ Molecular Biomedicine, and ${ }^{2}$ Cytopathology, School of Biological Sciences, Guerrero State University, Chilpanginco; ${ }^{3}$ Department of Pediatric Oncology, 'Arturo Beltrán Ortega' Cancer Institute, Acapulco, Guerrero, Mexico
\end{abstract}

Received October 6, 2011; Accepted December 6, 2011

DOI: $10.3892 /$ etm.2012.447

\begin{abstract}
Dihydrofolate reductase (DHFR) is the major target of methotrexate, a key component in childhood acute lymphoblastic leukemia (ALL) treatment. Polymorphisms in the gene coding for DHFR have been associated with adverse event treatment. This study evaluated the effect of the $-\mathrm{A} 317 \mathrm{G}$ and C829T polymorphisms in the DHFR gene on survival and risk of relapse of ALL. Seventy patients with ALL and 100 healthy individuals were genotyped by the polymerase chain reactionrestriction fragment length polymorphism method. An association between the polymorphisms and the risk of relapse was found $(\mathrm{p}<0.05)$; patients with the $-317 \mathrm{G} / \mathrm{G}$ genotype were found to have an 8.55 (95\% CI 1.84-39.70) higher chance of relapse and carriers of the $829 \mathrm{~T} / \mathrm{T}$ genotype had a 14.0 (95\% CI 1.13-172.63) higher chance of relapse. Other variables, such as age and leukocyte count, were associated $(p<0.05)$ with the risk of relapse of the disease. Individuals with the $\mathrm{G} / \mathrm{G}$ and $\mathrm{T} / \mathrm{T}$ genotype of the $-\mathrm{A} 317 \mathrm{G}$ and $\mathrm{C} 829 \mathrm{~T}$ polymorphisms had poorer survival compared to other genotype groups (log-rank test; $\mathrm{p}<0.05)$. Although preliminary, these data seem to suggest a role for the DHFR polymorphisms in the risk of relapse of ALL and the mortality risk in these patients.
\end{abstract}

Correspondence to: Dr Marco Antonio Leyva-Vázquez, Laboratorio de Biomedicina Molécular, Unidad Académica de Ciencias Químico Biológicas, Universidad Autónoma de Guerrero, Av. Lázaro Cárdenas S/N, Ciudad Universitaria, Chilpancingo, Guerrero 39090, México

E-mail: leyvamarco13@gmail.com

*Contributed equally

Key words: acute lymphoblastic leukemia, dihydrofolate reductase, risk of relapse, -A317G polymorphism, C829T polymorphism, survival in acute lymphoblastic leukemia

\section{Introduction}

In Mexico, acute leukemia is considered a public health issue; it represents the fourth leading cause of mortality of all neoplastic malignancies in children under 15 years of age (1). The mortality rate from 1996 to 2000 was 63.7 per 1 million children, one of the highest rates reported in the world (2). In 2005 , leukemia was the second cause of mortality in the State of Guerrero in children less than 15 years of age, according to the National Institute of Statistics, Geography and Computing (INEGI) (3).

Methotrexate (MTX) is an antineoplastic agent used in the treatment of patients with acute lymphoblastic leukemia (ALL) and was introduced five decades ago to clinical oncology. It is presently used in the treatment of other neoplastic diseases, including osteosarcoma, breast cancer, head and neck cancer, and non-Hodgkin's lymphoma (4,5). MTX is a folic acid antagonist, and its efficacy as an antineoplastic treatment is largely attributed to its high affinity for dihydrofolate reductase (DHFR) (EC 1.5.1.3), the enzyme which is responsible to catalyze the reduction of dihydrofolate (DHF) to tetrahydrofolate (THF) (6). The major mechanism of MTX action involves competitive inhibition of DHFR, leading to the impaired regeneration of THF from DHF; essential for the biosynthesis of purines and thymidylate, thus it also blocks the novo synthesis of DNA $(7,8)$. A subset of patients develop adverse events of resistance to MTX; however, approximately $80 \%$ of ALL children experience good clinical response $(5,9,10)$.

The mechanisms that lead to clinical failure to MTX are DHFR overexpression, impaired intracellular transport and decreased levels of reduced folate carrier at the cell membrane $(11,12)$. Changes in the levels of DHFR expression and consequently in the sensitivity to MTX can also be due to single nucleotide polymorphisms (SNPs), particularly those located in the regulatory elements. The C829T SNP is located at the 223 nucleotide downstream from the stop codon between the first and second polyadenylation sites in the 3'UTR of the DHFR gene, which leads to the stability of mRNA (13). A previous study reported that the $-\mathrm{A} 317 \mathrm{G}$ SNP in the DHFR promoter region results in higher transcriptional activity (14). 
The -A317G and C829T SNPs in the DHFR gene have not been studied as a factor for the risk of relapse to ALL in Mexico. In the present study, our objective was to evaluate the effect of the $-\mathrm{A} 317 \mathrm{G}$ and C829T polymorphisms in the DHFR gene on survival and risk of relapse of ALL.

\section{Materials and methods}

Study population. A case control study was carried out in the Pediatric Oncology Service of the State Cancer Institute (SCI) from the South of Mexico (Acapulco, Guerrero), between September 1996 and May 2009. The cases consisted of 70 patients diagnosed with ALL through bone marrow aspirate based on French-American-British morphological criteria, cytochemical staining properties and immunophenotyping of blast cells.

The diagnosis of ALL was further subclassified as T-lineage $\left(\mathrm{CD}^{+}, \mathrm{CD}^{+}\right.$plus $\mathrm{CD}^{+}$or $\mathrm{CD}^{+}$, or both) or B-lineage $\left(\mathrm{CD} 22^{+}\right.$, $\left.\mathrm{CD}_{19}{ }^{+}, \mathrm{HLA}_{-} \mathrm{DR}^{+}, \mathrm{CD} 10^{+}\right)$. Patients were treated with VDCPM (vincristine $1.4 \mathrm{mg} / \mathrm{m}^{2}$ at days $1,8,15$ and 22 , daunorubicin $45 \mathrm{mg} / \mathrm{m}^{2}$ at days $1-3$, cyclophosphamide $0.75 \mathrm{mg} / \mathrm{m}^{2}$ at days 1 and 15 , prednisone $40 \mathrm{mg} / \mathrm{m}^{2}$ at days $1-28$ and intrathecal methotrexate $8 \mathrm{mg} / \mathrm{m}^{2}$ for $1-2$ years, $10 \mathrm{mg} / \mathrm{m}^{2}$ for $2-3$ years, $12 \mathrm{mg} / \mathrm{m}^{2}$ for $3-8$ years and $15 \mathrm{mg} / \mathrm{m}^{2}$ for $>8$ years) or VDLPM (vincristine $1.4 \mathrm{mg} / \mathrm{m}^{2}$ at days $1,8,15$ and 22, daunorubicin $45 \mathrm{mg} / \mathrm{m}^{2}$ at days $1-3$, asparaginase $6,000 \mathrm{U} / \mathrm{m}^{2}$ at days $19-28$, prednisone $40 \mathrm{mg} / \mathrm{m}^{2}$ at days $1-28$ and intrathecal methotrexate $8 \mathrm{mg} / \mathrm{m}^{2}$ for $1-2$ years, $10 \mathrm{mg} / \mathrm{m}^{2}$ for $2-3$ years, $12 \mathrm{mg} / \mathrm{m}^{2}$ for $3-8$ years and $15 \mathrm{mg} / \mathrm{m}^{2}$ for $>8$ years) regimens (15).

Complete remission was defined by $<5 \%$ blast cells in the bone marrow and normalization of peripheral blood counts at 4 weeks after starting induction therapy (16). Relapse was defined as the reappearance of $>20 \%$ blast cells in the marrow, or the presence of localized leukemic infiltrates at any site after completion of induction chemotherapy (16). Worse outcome was defined as a lack of response to induction therapy, a relapse after achieving complete remission or death due to any cause (16). Risk classification: standard risk: 1-9 years of age and presenting white blood cell (WBC) count of $<50,000 / \mathrm{mm}^{3}$; high risk: $<1$ and $>9$ years of age and WBC count $>50,000 / \mathrm{mm}^{3}$ (17). The controls were 100 healthy individuals $\left(4-10 \times 10^{3}\right.$ leukocytes $\left./ \mathrm{mm}^{3}\right)$ without a family history of leukemia. Subjects in both groups in the study were 1-18 years of age, included both genders and were residence in the State of Guerrero, Mexico.

Specimen collection. A bone marrow and/or blood sample was taken from the 170 participants and placed in tubes with anticoagulant. Leukocytes were purified from the whole blood sample by a selective osmotic lysis of erythrocytes; the leukocyte genomic DNA and RNA total was extracted by the phenol-chloroform technique (18).

Genotyping of the $-A 317 G$ and $C 829 T$ polymorphisms in the DHFR. The $-\mathrm{A} 317 \mathrm{G}$ polymorphism (dbSNP; rs408626) was detected using previously reported PCR primers (14): forward primer 5'-GTAGGTTCTGTCTGGGACTGG-3' and reverse primer 5'-GCAGCTTTCTTCTAGTCACCC-3'; and using previously established protocols (19). The PCR products (400 bp) were digested with 4 units of the HinfI enzyme
Table I. General characteristics of the population and clinical data of patients with childhood acute lymphoblastic leukemia (ALL) and healthy individuals.

\begin{tabular}{|c|c|c|}
\hline Variable & $\begin{array}{l}\text { Patients } \\
\text { with ALL } \\
(\mathrm{n}=70)\end{array}$ & $\begin{array}{c}\text { Healthy } \\
\text { individuals } \\
(n=100)\end{array}$ \\
\hline Age (years; mean $\pm \mathrm{SD}$ ) & $7.65 \pm 4.67$ & $9.99 \pm 5.49$ \\
\hline No. of leukocytes $/ \mathrm{mm}^{3}$ & $\begin{array}{c}13,000 \\
(5,400-39,000)^{\mathrm{a}}\end{array}$ & $\begin{array}{c}8,000 \\
(7,000-9,000)^{\mathrm{a}}\end{array}$ \\
\hline \multicolumn{3}{|l|}{ Gender } \\
\hline Male & $45(64.29)$ & $53(53.00)$ \\
\hline Female & $25(35.71)$ & $47(47.00)$ \\
\hline \multicolumn{3}{|l|}{ Status of participants } \\
\hline Alive & $30(42.86)$ & $100(100)$ \\
\hline Deceased & $40(57.14)$ & 0 \\
\hline \multicolumn{3}{|l|}{ Immunophenotype } \\
\hline B-lineage & $66(94.28)$ & 0 \\
\hline T-lineage & $4(5.72)$ & 0 \\
\hline \multicolumn{3}{|l|}{ Risk by age } \\
\hline Standard (1-9 years) & $18(25.71)$ & 0 \\
\hline High $(<1$ and $>9$ years $)$ & $52(74.29)$ & 0 \\
\hline \multicolumn{3}{|l|}{ Relapse during treatment } \\
\hline No & $22(31.43)$ & 0 \\
\hline Yes & $48(68.57)$ & 0 \\
\hline
\end{tabular}

Data indicate n (\%); ${ }^{\mathrm{a}}$ median (percentiles 25-75).

(Invitrogen Life Technologies, USA). Individuals with the A/A genotype presented two fragments (266 and $134 \mathrm{bp}$ ), individuals with the $\mathrm{A} / \mathrm{G}$ genotype presented four fragments (266, 134,83 and $51 \mathrm{bp}$ ) and those with the G/G genotype presented three fragments $(266,83$ and $51 \mathrm{bp})$.

The C829T polymorphism (ddsSNP; rs34764978) was detected using previously reported PCR primers (20): forward primer 5'-CTTCTCCAAGACCCCAACTG-3' and reverse primer 5'-CTTCCAGGTTGTTTTCAATTTTT-3'; and using previously established protocols (19), The amplified products (269 bp) were digested with 3 units of the TspRI enzyme (New England Biolabs, Berverly, MA, USA). The C/C genotype presented three fragments $(203,36$ and $30 \mathrm{bp})$, the C/T genotype presented four fragments $(239,203,36$ and $30 \mathrm{bp})$ and the T/T genotype presented two fragments (239 and $30 \mathrm{bp}$ ).

Statistical analysis. Continuous data are presented as the means \pm standard deviation or median, 25th and 75th interquartiles. Categorical data were compared by Chi-square or Fisher's exact test. Univariate logistic regression analysis for the association with the risk of relapse of ALL was tested first for -A317G and C829T genetic polymorphisms, gender and other clinical characteristics, and those factors were included into a second multivariate logistic analysis. The log-rank test and Kaplan-Meier curves were used to analyze the effect of the $-\mathrm{A} 317 \mathrm{G}$ and C829T genetic polymorphisms, gender and relapse of ALL on overall survival (OS). OS was 
Table II. Genotype and allele frequencies of DHFR SNPs in the childhood acute lymphoblastic leukemia (ALL) cases and controls, and association with risk of ALL.

\begin{tabular}{|c|c|c|c|c|c|c|c|c|}
\hline Model $^{\mathrm{a}}$ & Genotype & $\begin{array}{l}\text { ALL cases } \\
\quad(n=70)\end{array}$ & $\begin{array}{l}\text { Controls } \\
(n=100)\end{array}$ & p-value ${ }^{b}$ & OR & $95 \% \mathrm{CI}$ & p-value ${ }^{c}$ & $\begin{array}{c}\text { p-value } \\
\text { HWE }\end{array}$ \\
\hline \multicolumn{9}{|c|}{-A317G (rs408626) } \\
\hline \multirow[t]{3}{*}{ Co } & $\mathrm{A} / \mathrm{A}$ & $14(20.00)$ & $36(35.00)$ & $0.037^{\mathrm{e}}$ & 1.00 & & & $0.152^{\mathrm{d}}$ \\
\hline & $\mathrm{A} / \mathrm{G}$ & $33(47.14)$ & $42(43.57)$ & & 2.24 & $1.03-4.88$ & $0.042^{\mathrm{e}}$ & \\
\hline & $\mathrm{G} / \mathrm{G}$ & $23(32.86)$ & $22(21.43)$ & & 2.89 & $1.22-6.86$ & $0.016^{\mathrm{e}}$ & \\
\hline \multirow[t]{2}{*}{ Do } & $\mathrm{A} / \mathrm{A}$ & $14(20.00)$ & $36(35.00)$ & & 1.00 & & & \\
\hline & $\mathrm{A} / \mathrm{G}+\mathrm{G} / \mathrm{G}$ & $56(80.00)$ & $64(65.00)$ & & 2.47 & $1.19-5.11$ & $0.015^{\mathrm{e}}$ & \\
\hline \multirow[t]{5}{*}{$\mathrm{Re}$} & $\mathrm{A} / \mathrm{A}+\mathrm{AG}$ & $47(67.14)$ & $78(78.57)$ & & 1.00 & & & \\
\hline & $\mathrm{G} / \mathrm{G}$ & $23(32.86)$ & $22(21.43)$ & & 1.74 & $0.87-3.45$ & 0.116 & \\
\hline & Allele & & & & & & & \\
\hline & A & $61(43.57)$ & $114(57.00)$ & $0.011^{\mathrm{e}}$ & 1.00 & & & \\
\hline & G & $79(56.43)$ & $86(43.00)$ & & 1.73 & $1.12-2.68$ & $0.014^{\mathrm{e}}$ & \\
\hline \multicolumn{9}{|c|}{ C829T (rs34764978) } \\
\hline \multirow[t]{3}{*}{$\mathrm{Co}$} & $\mathrm{C} / \mathrm{C}$ & $10(14.29)$ & $33(33.00)$ & $0.016^{\mathrm{e}}$ & 1.00 & & & $0.077^{\mathrm{d}}$ \\
\hline & $\mathrm{C} / \mathrm{T}$ & $53(75.71)$ & $56(56.00)$ & & 2.83 & $1.27-6.33$ & $0.011^{\mathrm{e}}$ & \\
\hline & $\mathrm{T} / \mathrm{T}$ & $7(10.00)$ & $11(11.00)$ & & 1.97 & $0.60-6.46$ & 0.261 & \\
\hline \multirow[t]{2}{*}{ Do } & $\mathrm{C} / \mathrm{C}$ & $10(14.29)$ & $33(33.00)$ & & 1.00 & & & \\
\hline & $\mathrm{C} / \mathrm{T}+\mathrm{T} / \mathrm{T}$ & $60(85.71)$ & $67(67.00)$ & & 2.69 & $1.22-5.95$ & $0.014^{\mathrm{e}}$ & \\
\hline \multirow[t]{5}{*}{$\mathrm{Re}$} & $\mathrm{C} / \mathrm{C}+\mathrm{C} / \mathrm{T}$ & $63(90.00)$ & $89(89.00)$ & & 1.00 & & & \\
\hline & $\mathrm{T} / \mathrm{T}$ & $7(10.00)$ & $11(11.00)$ & & 0.89 & $0.33-2.44$ & 0.835 & \\
\hline & Allele & & & & & & & \\
\hline & $\mathrm{C}$ & $73(52.14)$ & $122(61.00)$ & 0.119 & 1.00 & & & \\
\hline & $\mathrm{T}$ & $67(47.86)$ & $78(39.00)$ & & 1.38 & $0.89-2.12$ & 0.151 & \\
\hline
\end{tabular}

Data indicate $\mathrm{n}(\%)$. ${ }^{\mathrm{a}}$ Genetic model: Co, codominant, Do, dominant, Re, recessive. ${ }^{\mathrm{b}}$ Obtained by the Chi-square test. ${ }^{\mathrm{c}}$ Obtained by the logistic regression analysis, taking reference to AA and CC genotypes; ${ }^{\mathrm{H}} \mathrm{HWE}$ (Hardy-Weinberg equilibrium) to controls. OR, odds ratio; 95\% CI, 95\% confidence interval. ${ }^{e}$ Significant $\mathrm{p}<0.05$.

defined as the time between surgery and either death or the time of the last follow-up. The Hardy-Weinberg equilibrium (HWE) was used to determine the genetic equilibrium in the healthy group. $\mathrm{p}<0.05$ was considered statistically significant. All statistical analyses were performed using SPSS software, version 15.0 (SPSS Inc., Chicago, IL, USA) and STATA software, version 9.2 (StataCorp, College Station, TX, USA).

Ethics statement. The bone marrow samples of the patients and blood samples of healthy individuals used in this study were part of the samples taken for clinical diagnostic tests in the hospital. Since no extra amount of samples was collected from the study subjects, informed consent was obtained from all the individuals or their guardians, after a detailed briefing of the study purposes. The study and the informed consent procedure were approved by the Institutional Review Board of the Cancer Institute from Guerrero State, Mexico.

\section{Results}

Characteristics of the study population. The 70 ALL patients had ages ranging from 1.0 to 18 years (mean $\pm \mathrm{SD}, 7.65 \pm 4.67$ years). There were $45(64.29 \%)$ males and $25(35.71 \%)$ females. Eighteen patients $(25.71 \%)$ were in the age group of 1-9 years (standard risk). Fifty-two patients (72.29\%) were $<1$ year and $>9$ years of age (high risk) at the time of initial diagnosis. Relapse of ALL occurred in $68.57 \%$ of the patients. WBC and characteristics of immunophenotype are depicted in Table I.

We also included 100 control subjets (controls). In this group, the age range was $1-18$ years (mean $\pm \mathrm{SD}, 9.99 \pm 5.49$ years), and the leukocyte count was normal $\left(4-10 \times 10^{3}\right.$ leucocytes/ $\mathrm{mm}^{3}$; median 8,000$)$. In this group, 53 healthy individuals $(53 \%)$ were male and $47(47 \%)$ were female (Table I).

Associations of $-A 317 G$ and C829T SNP of DHFR with risk of $A L L$. The allele and genotype distributions for two SNPs of DHFR in the cases and controls are summarized in Table II. The genotype frequencies of these polymorphisms were in HWE ( $p>0.05$ ) in the controls. When the genotype frequencies were compared between cases and controls, they showed a statistically significant association with the disease. The distribution of -A317G and C829T SNP genotypes was significant between the cases and controls $(\mathrm{p}=0.037$ and $\mathrm{p}=0.016$, respectively), and the $\mathrm{A} / \mathrm{G}$ and $\mathrm{C} / \mathrm{T}$ genotypes were more prevalent among the patients (47.14 and $75.71 \%$, respectively). The homozygous variant $\mathrm{G} / \mathrm{G}$ [odds ratio $(\mathrm{OR})=2.89,95 \% \mathrm{CI}$ 1.22-6.86] and heterozygote variant $\mathrm{C} / \mathrm{T}(\mathrm{OR}=2.83,95 \% \mathrm{CI}$ 1.03-4.88) were risk factors for ALL (Table II). 
Table III. Genotype distribution and allele frequency of the -A317G and C829T polymorphisms of DHFR in individuals with and without relapse of childhood acute lymphoblastic leukemia.

\begin{tabular}{ccc}
\hline Without & With & p-value \\
& relapse & relapse \\
$\mathrm{n}(\%)$ & $\mathrm{n}(\%)$ & \\
\hline
\end{tabular}

\begin{tabular}{lrrr}
-A317G (rs408626) & & \\
Genotypes & $9(40.91)$ & $4(8.33)$ & \\
A/A & $9(40.91)$ & $25(52.08)$ & \\
A/G & $4(18.18)$ & $19(39.58)$ & $0.014^{\mathrm{b}}$ \\
G/G & & & \\
Allele & $27(61.36)$ & $34(35.42)$ & \\
A & $17(38.64)$ & $62(64.58)$ & $0.004^{\mathrm{b}}$ \\
G & & & \\
C829T (rs34764978) & & & \\
Genotypes & $7(31.82)$ & $3(6.25)$ & \\
C/C & $14(63.64)$ & $39(81.25)$ & \\
C/T & $1(4.54)$ & $6(12.50)$ & $0.015^{\mathrm{b}}$ \\
T/T & & & \\
Allele & $28(63.64)$ & $45(46.88)$ & \\
C & $16(36.36)$ & $51(53.12)$ & $0.048^{\mathrm{b}}$ \\
T & & & \\
\hline
\end{tabular}

abtained by the Chi-square test; ${ }^{\mathrm{b}}$ Significant $\mathrm{p}<0.05$.

Genotype distribution and allele frequency of SNPS in individuals with and without relapse of ALL. The A/A genotype was present in $10.42 \%$ of the patients with relapse, compared to $40.91 \%$ of those who did not relapse, whereas $50 \%$ of the patients with relapse were carriers of the $\mathrm{A} / \mathrm{G}$ genotype compared to $40.91 \%$ of those who did not relapse, and $39.58 \%$ of the patients with relapse were carriers of the G/G genotype, compared to $18.18 \%$ of those who did not relapse. Regarding the distribution of the C829T polymorphism in patients with relapse, $81.25 \%$ were carriers of the $\mathrm{C} / \mathrm{T}$ genotype, $12.50 \%$ had the $\mathrm{T} / \mathrm{T}$ genotype and only $6.25 \%$ carried the $\mathrm{C} / \mathrm{C}$ genotype. In contrast to those who did not relapse, $31.82 \%$ were carriers of the $\mathrm{C} / \mathrm{C}$ genotype, $63.64 \%$ of the $\mathrm{C} / \mathrm{T}$ genotype and $4.54 \%$ carriers of the $\mathrm{T} / \mathrm{T}$ genotype. Genotypic and allelic frequencies of both polymorphisms were statistically significant between patients with and without relapse of ALL $(\mathrm{p}<0.05)$ (Table III).

Risk of relapse based on the -A317G and C829T SNP genotypes and other risk factors in ALL. In a logistic regression analysis, an association was found between the -A317G, C829T polymorphisms and the risk of relapse of disease $(\mathrm{p}<0.05)$. Those patients carrying the $\mathrm{G} / \mathrm{G}$ genotype of the $-\mathrm{A} 317 \mathrm{G}$ polymorphism, showed a significant increase in the risk of relapse of $\mathrm{ALL}(\mathrm{OR}=8.55,95 \% \mathrm{CI}$ 1.84-39.70) compared to carriers of the A/A genotype $(\mathrm{p}=0.006)$ (Table IV). Carriers of the $\mathrm{T} / \mathrm{T}$ genotype of the C829T polymorphism had a 14.00 greater chance of a relapse of the disease $(\mathrm{OR}=14.00$, 95\% CI 1.13-172.63) compared to carriers of the C/C genotype $(\mathrm{p}=0.039)$ (Table IV). Other variables, such as age, leukocytes, but not gender, were associated with the risk of relapse of disease $(\mathrm{p}<0.05)$ (Table IV).

The following variables were included in a multivariate analysis: leukocytes count at diagnosis, age, -A317G and C829T polymorphism genotypes, to determine whether either or both the SNPs predict the risk of relapse independently. It was observed that $\mathrm{A} / \mathrm{G}$ or $\mathrm{G} / \mathrm{G}$ genotype carriers $(\mathrm{p}=0.041$ and $\mathrm{p}=0.017$, respectively), together with the $\mathrm{C} / \mathrm{T}$ or $\mathrm{T} / \mathrm{T}$ genotype carriers $(p=0.015$ and $p=0.049$, respectively), were two independent prognostic markers for the risk of relapse of ALL compared to the other variables (Table V).

Association between DHFR -A317G and C829T SNP and overall survival in the ALL patients. Kaplan-Meier analysis of OS curves showed significant results between the relapse of ALL and DHFR -A317G, C829T polymorphisms. We found no significant associations between gender and OS (log-rank test; $\mathrm{p}=0.79$ ) (Fig. 1A). A different rate of OS was evident between the individuals with and without relapse of ALL (log-rank test; p<0.001) (Fig. 1B). In fact, $81.82 \%$ of the patients without relapse were alive, while only $25 \%$ of patients with relapse were alive (Table I). Those patients with relapse had a 13.5 greater chance of death $(\mathrm{OR}=13.5,95 \% \mathrm{CI}$ 3.81-47.84) compared to those without relapse $(\mathrm{p}<0.001)$ (data not shown).

The relationship between OS and the polymorphisms was calculated. Individuals with the $\mathrm{G} / \mathrm{G}$ genotype had poorer OS compared to the A/A genotype (log-rank test; $\mathrm{p}<0.05$ ) (Fig. 1C and D). We found no significant association for the DHFR C829T polymorphism, although we observed a reduction in survival at 11 years of follow-up among T/T-carriers with respect to that of patients with the wild-type genotype (log-rank test; $\mathrm{p}=0.069$ ) (Fig. 1E). However, we carried out log-rank test for combined genotypes, $\mathrm{C} / \mathrm{T}+\mathrm{T} / \mathrm{T}$ vs. $\mathrm{C} / \mathrm{C}$ (Fig. 1F), showing significant genotype-dependent effects for OS (log-rank test; $\mathrm{p}=0.026$ ).

\section{Discussion}

There have been attempts to explain the mechanisms by which patients show different response to the same drug used to treat ALL. However, there are few studies addressing the association of SNPs with response to treatment in patients with ALL. There are no studies in Mexico regarding the $-317 \mathrm{~A} / \mathrm{G}$ and $829 \mathrm{C} / \mathrm{T}$ polymorphisms of DHFR; therefore, it is important to determine their distribution in the Mexican population, its association and impact on the risk of relapse and survival in patients with ALL.

Patients with ALL predominantly showed the heterozygous A/G genotype (47.14\%) of the -A317G polymorphism (Table II), a result similar to that reported by Dulucq et al, in a Canadian population where the $\mathrm{A} / \mathrm{G}$ genotype was reported as the most frequent in individuals with ALL (48.4\%) (14). However, the genotypic frequencies A/A (31.4\%), A/G (48.4\%) and $\mathrm{G} / \mathrm{G}(20.2 \%)$ reported by Dulucq et al are statistically significant to those found in this study $(\mathrm{p}=0.040)$.

The genotypic frequencies of the C829T polymorphism reported in this study differ $(\mathrm{p}<0.001)$ from those reported by Goto et al, in a Japanese population with ALL, where the C/C genotype $(83.8 \%)$ was the most frequently reported, followed 
Table IV. Association of the -A317G and C829T polymorphisms in the DHFR gene and other clinical features with the risk of relapse of childhood acute lymphoblastic leukemia.

\begin{tabular}{|c|c|c|c|c|c|}
\hline Model $^{\mathrm{a}}$ & Genotype & No. $(\%)$ & OR & $95 \% \mathrm{CI}$ & p-value ${ }^{b}$ \\
\hline \multicolumn{6}{|l|}{-A317G (rs408626) } \\
\hline \multirow[t]{3}{*}{ Co } & $\mathrm{A} / \mathrm{A}$ & $14(20.00)$ & 1.00 & & \\
\hline & $\mathrm{A} / \mathrm{G}$ & $33(47.14)$ & 4.80 & $1.26-18.24$ & $0.021^{\mathrm{c}}$ \\
\hline & $\mathrm{G} / \mathrm{G}$ & $23(32.86)$ & 8.55 & $1.84-39.70$ & $0.006^{\mathrm{c}}$ \\
\hline \multirow[t]{2}{*}{ Do } & $\mathrm{A} / \mathrm{A}$ & $14(20.00)$ & 1.00 & & \\
\hline & $\mathrm{A} / \mathrm{G}+\mathrm{G} / \mathrm{G}$ & $56(80.00)$ & 7.62 & $2.01-28.81$ & $0.003^{\mathrm{c}}$ \\
\hline \multirow[t]{2}{*}{$\mathrm{Re}$} & $\mathrm{A} / \mathrm{A}+\mathrm{AG}$ & $47(67.14)$ & 1.00 & & \\
\hline & $\mathrm{G} / \mathrm{G}$ & $23(32.86)$ & 2.94 & 0.86-10.06 & 0.084 \\
\hline \multicolumn{6}{|l|}{ C829T (rs34764978) } \\
\hline \multirow[t]{3}{*}{$\mathrm{Co}$} & $\mathrm{C} / \mathrm{C}$ & $10(14.29)$ & 1.00 & & \\
\hline & $\mathrm{C} / \mathrm{T}$ & $53(75.71)$ & 6.50 & $1.47-28.67$ & $0.013^{\mathrm{c}}$ \\
\hline & $\mathrm{T} / \mathrm{T}$ & $7(10.00)$ & 14.00 & $1.13-172.63$ & $0.039^{\mathrm{c}}$ \\
\hline \multirow[t]{2}{*}{ Do } & $\mathrm{C} / \mathrm{C}$ & $10(14.29)$ & 1.00 & & \\
\hline & $\mathrm{C} / \mathrm{T}+\mathrm{T} / \mathrm{T}$ & $60(85.71)$ & 7.00 & $1.60-30.54$ & $0.010^{\mathrm{c}}$ \\
\hline \multirow[t]{2}{*}{$\operatorname{Re}$} & $\mathrm{C} / \mathrm{C}+\mathrm{C} / \mathrm{T}$ & $63(90.00)$ & 1.00 & & \\
\hline & $\mathrm{T} / \mathrm{T}$ & $7(10.00)$ & 3.00 & $0.348-26.55$ & 0.323 \\
\hline \multicolumn{6}{|l|}{ Gender } \\
\hline Female & & $25(35.71)$ & 1.00 & & \\
\hline Male & & $45(64.29)$ & 1.38 & $0.49-3.92$ & 0.540 \\
\hline \multicolumn{6}{|l|}{ Risk by age } \\
\hline 1-9 years (low risk) & & $18(25.71)$ & 1.00 & & \\
\hline$<1$ and >9 years (high risk) & & $52(74.29)$ & 4.54 & $1.14-18.09$ & $0.032^{\mathrm{c}}$ \\
\hline \multicolumn{6}{|l|}{ Leukocytes at diagnosis } \\
\hline$<50,000 / \mathrm{mm}^{3}$ & & $18(25.71)$ & 1.00 & & \\
\hline$>50,000 / \mathrm{mm}^{3}$ & & $52(74.29)$ & 7.64 & $1.90-30.73$ & $0.004^{\mathrm{c}}$ \\
\hline
\end{tabular}

${ }^{\mathrm{a}}$ Genetic model: Co, codominant; Do, dominant; Re, recessive. ${ }^{\mathrm{b} O b t a i n e d ~ b y ~ l o g i s t i c ~ r e g r e s s i o n ~ a n a l y s i s ; ~}{ }^{\mathrm{c}}$ Significant $\mathrm{p}<0.05$; OR, odds ratio; 95\% CI, 95\% confidence interval.

Table V. Factors influencing the risk of relapse of ALL in a multivariate regression analysis.

\begin{tabular}{lrrr}
\hline & OR & $95 \%$ CI & p-value \\
\hline -A317G (rs408626) & & & \\
A/G & 4.06 & $0.01-0.58$ & $0.041^{\mathrm{b}}$ \\
G/G & 6.75 & $0.07-0.67$ & $0.017^{\mathrm{b}}$ \\
C829T (rs34764978) & & & \\
C/T & 7.49 & $0.08-0.71$ & $0.015^{\mathrm{b}}$ \\
T/T & 12.38 & $0.002-0.93$ & $0.049^{\mathrm{b}}$ \\
Risk by age & & & \\
$\quad<1$ and >9 years (high risk) & 0.86 & $0.25-2.96$ & 0.814 \\
Leukocytes at diagnosis & & & \\
$>50,000 / \mathrm{mm}^{3}$ & 0.52 & $0.11-2.36$ & 0.395 \\
\hline
\end{tabular}

OR, odds ratio; $95 \%$ CI, 95\% confidence interval. a Obtained by multivariate logistic regression analysis. ${ }^{\mathrm{b} S i g n i f i c a n t} \mathrm{p}<0.05$.

by the $\mathrm{C} / \mathrm{T}$ genotype (10.8\%) and the T/T genotype (5.4\%) (13). The C829T polymorphism has been studied in other disorders that involve the metabolic pathway of folate. However, it was not identified in non-Japanese American, Caucasian or Israeli populations (21-23), suggesting that the C829T polymorphism was found more frequently in patients with ALL than in other disorders in which the activity enzymatic of DHFR is involved.

In the present study, $93.75 \%$ of the patients with relapse were carriers of the $\mathrm{T}$ allele (Table III); this agrees with previous experimental studies, which identified the $\mathrm{T}$ allele as a risk for relapse to ALL (28). This suggests that the presence of the $-\mathrm{A} 317 \mathrm{G}$ and $\mathrm{C} 829 \mathrm{~T}$ polymorphisms, and the strong association with the risk of relapse $(\mathrm{p}<0.05)$ (Table IV) may be a factor that led to more than $50 \%$ of deaths in the patients with ALL included in this study.

In many studies, age has been found to be a prognostic factor in childhood ALL (24); this feature also retained its significance in our study. Patients in the age group of 1-9 years (low risk) had the best prognosis, whereas patients $<1$ and $>9$ years of age (high risk) showed the worst prognosis $(\mathrm{OR}=4.54,95 \%$ CI 1.14-18.09) (Table IV), which agrees with other studies (25).

Regarding gender, it has been reported in various studies that females have better survival than males of the same age 
A

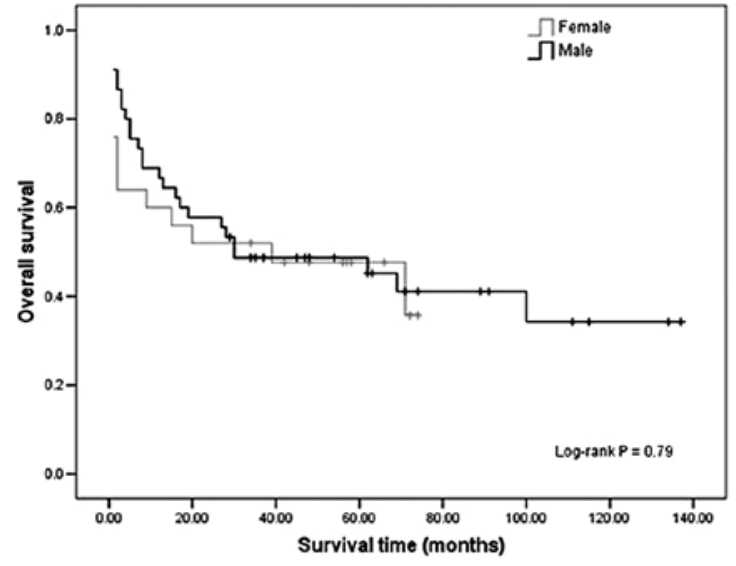

$\mathbf{C}$

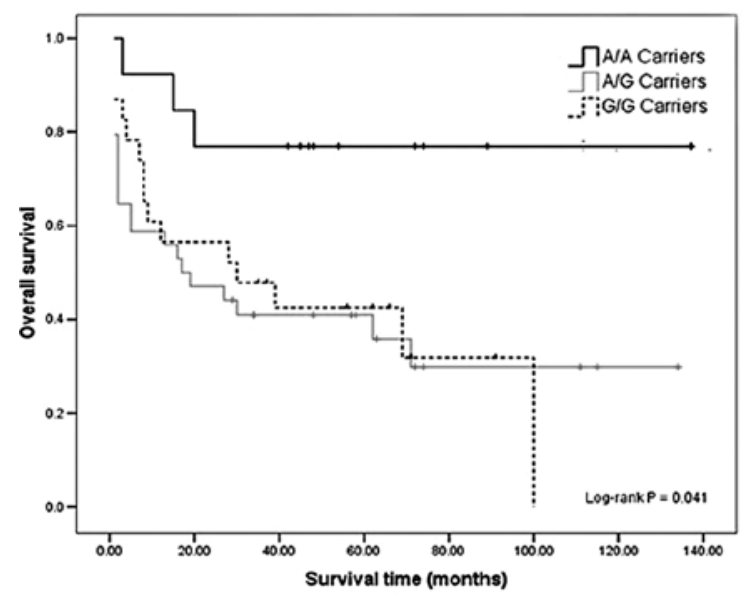

$\mathbf{E}$

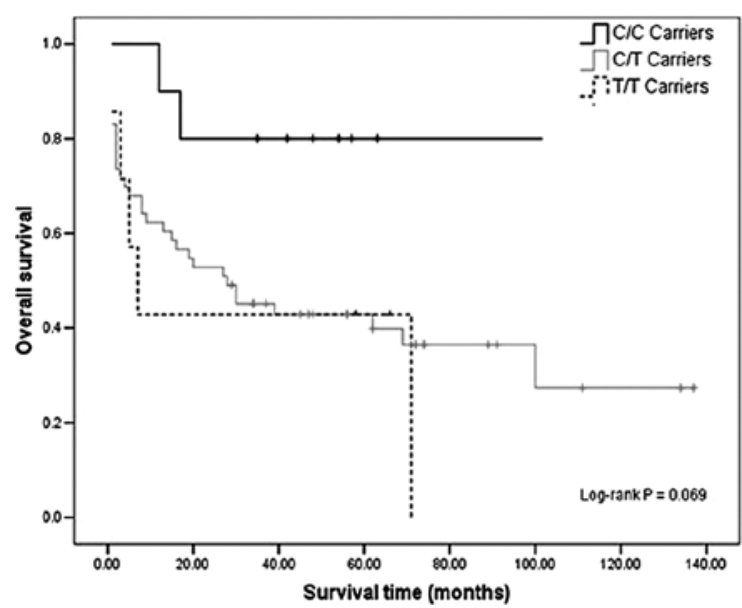

B

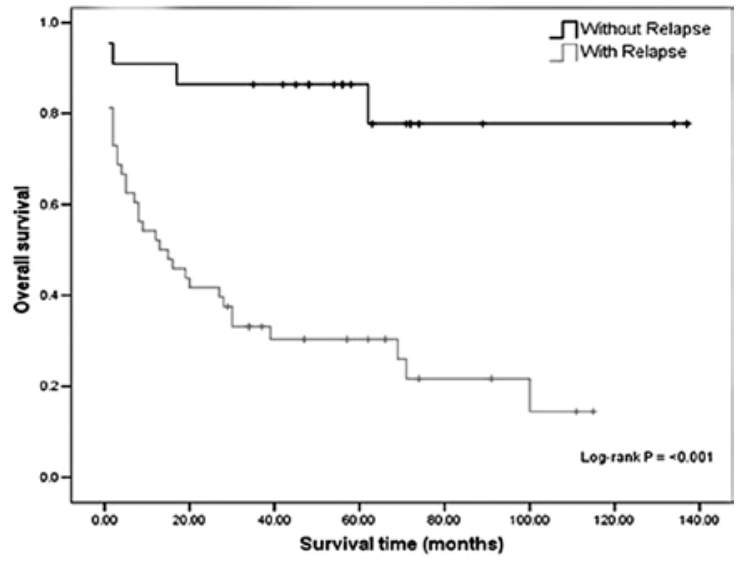

D

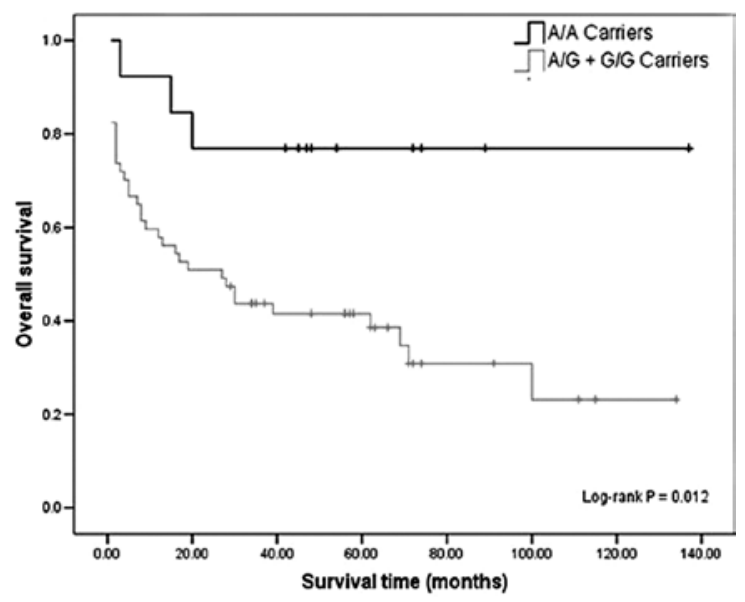

F

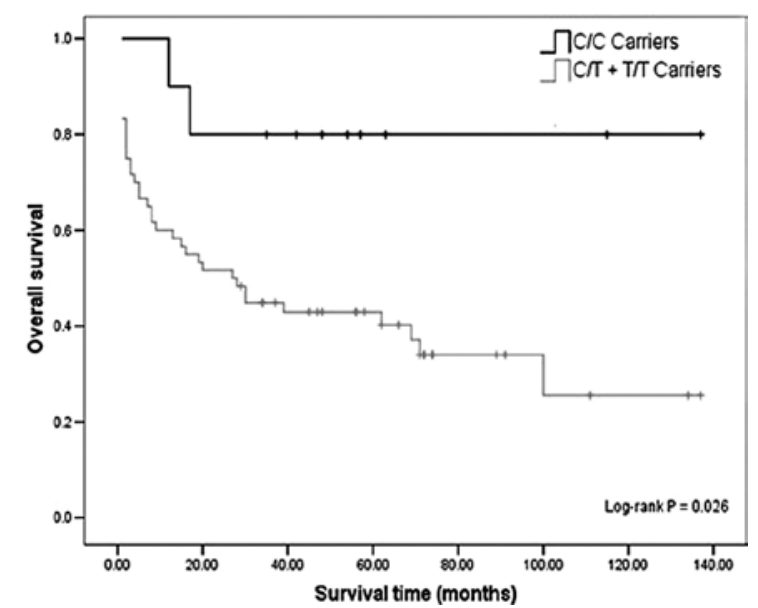

Figure 1. Kaplan-Meier curves considering the influence of gender, relapse, and dihydrofolate reductase (DHFR) -A317G and C829T polymorphisms on overall survival (OS) of acute lymphoblastic leukemia (ALL) patients. (A) OS in females and males with ALL. (B) OS between patients with and without relapse. (C) Association between OS and the DHFR -A317G polymorphism. (D) Combined genotypes A/G + G/G vs. A/A in 70 children with ALL. (E) Association between OS and the DHFR C829T polymorphism. (F) Combined genotypes C/T + T/T vs. C/C in 70 children with ALL. Ticks indicate censoring.

with ALL $(24,26)$. However, we did not observe such a genderbased outcome ( $\mathrm{p}>0.05)$ (Table IV), similarly to Dulucq et al, Kim et al and Dervieux et al, $(14,27,28)$. This could be due to the small sample size of the female group $(\mathrm{n}=25 / 70)$ in our study. The WBC has also been reported as a prognostic factor in many studies on pediatric ALL. We observed that a WBC count more than $50 \times 10^{9}$ leukocytes $/ \mathrm{mm}^{3}$ at diagnosis was associated with poor outcome (OR=7.64, 95\% CI 1.90-30.73)
(Table IV), similar to other studies $(24,29)$. Immunophenotype has been considered as the most important prognostic factor impacting the therapeutic strategy. The pre-B ALL and the immature T-cell precursor are generally associated with a poorer prognosis (30). Two studies have shown that the Hispanic population has a high frequency of B-cell precursor immunophenotype $(31,32)$. Our findings are consistent with these studies; we found that the $68.18 \%$ of cases with relapse 
of leukemia were classified within this immunological lineage (data not shown).

On separate analyses of the $-\mathrm{A} 317 \mathrm{G}$ and C829T polymorphisms in the DHFR gene, analyses of the $\mathrm{G} / \mathrm{G}$ and $\mathrm{T} / \mathrm{T}$ genotypes alone appear to be worse prognostic markers than leukocytes at diagnosis and age $(\mathrm{OR}=8.55,95 \%$ CI 1.84-39.70; $\mathrm{OR}=14.00,95 \%$ CI 1.13-172.63; OR=7.64, 95\% CI 1.90-30.73; $\mathrm{OR}=4.54,95 \%$ CI 1.14-18.09, respectively). However, in a multivariate analysis we observed that the $-\mathrm{A} 317 \mathrm{G}$ and C829T polymorphisms were the worst independent prognostic factors. The analysis showed that $\mathrm{G} / \mathrm{G}$ and $\mathrm{T} / \mathrm{T}$ genotypes were independent prognostic markers, excluding leukocytes at diagnosis and age (Table V). A second goal of this study was to investigate the impact of the polymorphisms on survival. The OS rate of $\mathrm{G}$ and $\mathrm{T}$ allele carriers of the $-\mathrm{A} 317 \mathrm{G}$ and C829T polymorphisms, respectively, was lower than that of patients carrying $\mathrm{A}$ and $\mathrm{C}$ alleles. Our results are in line with those reported by Dulucq et al (14), showing an association between the $\mathrm{G} / \mathrm{G}$ variant and reduced survival in ALL patients. We also evaluated the relationship between OS and the C829T polymorphism. During follow-up, we observed a reduction in OS among T-carriers and patients with the wild-type genotype (Fig. 1).

In conclusion, the $-\mathrm{A} 317 \mathrm{G}$ and C829T polymorphisms are strongly associated with the risk of relapse to ALL, presenting a higher risk of relapse in ALL carriers of $G / G$ and T/T genotypes than in carriers of the A/A and $\mathrm{C} / \mathrm{C}$ genotypes, respectively. Our data showed that the polymorphisms of DHFR C829T and -A317G had an impact on survival of ALL Mexican patients. These data seem to suggest a role for the DHFR polymorphisms in the relapse of ALL and overall survival. This is the first study which evaluated the effect of the C829T polymorphism on overall survival. However, this analysis was based only on 70 patients and needs to be confirmed in a larger population.

\section{Acknowledgements}

The authors would like to thank the National Council of Science and Technology (CONACYT, Mexico) for a fellowship awarded to Yazmín Gómez-Gómez (August 2007 to July 2009). They also thank the technicians of the Laboratorio de Biomedicina Molecular for their laboratory assistance, and Dinorah Leyva-Illades (Texas A\&M Health Science Center) for revising the English style of the manuscript.

\section{References}

1. Coronel-Morán QR: Importancia del laboratorio en el diagnóstico y pronóstico de leucemia aguda linfoblástica de la infancia. Acta Pediátrica de México 26: 129-136, 2005.

2. Mejia-Arangure JM, Bonilla M, Lorenzana R, et al: Incidence of leukemias in children from El Salvador and Mexico City between 1996 and 2000: population-based data. BMC Cancer 5: 33,2005

3. Salud/INEGI, S.d., Fuente: base de datos de defunciones INEGI/ Secretaria de Salud, Dirección General de Información en Salud, México. Información disponible en URL www.inegi.org.mx/ (Accessed April, 2008).

4. Cheok MH and Evans WE: Acute lymphoblastic leukaemia: a model for the pharmacogenomics of cancer therapy. Nat Rev Cancer 6: 117-129, 2006.

5. Hider SL, Bruce IN and Thomson W: The pharmacogenetics of methotrexate. Rheumatology (Oxford) 46: 1520-1524, 2007.
6. Wang L, Goodey NM, Benkovic SJ and Kohen A: Coordinated effects of distal mutations on environmentally coupled tunneling in dihydrofolate reductase. Proc Natl Acad Sci USA 103: 15753-15758, 2006.

7. Volpato JP, Fossati E and Pelletier JN: Increasing methotrexate resistance by combination of active-site mutations in human dihydrofolate reductase. J Mol Biol 373: 599-611, 2007.

8. Allemann RK, Evans RM, Tey LH, et al: Protein motions during catalysis by dihydrofolate reductases. Philos Trans R Soc Lond B Biol Sci 361: 1317-1321, 2006.

9. Fotoohi AK: Resistance of human leukaemia cells to the antimetabolites. Oncology-Pathology, Suecia 1: 1-84, 2007.

10. Serra M, Reverter-Branchat G, Maurici D, et al: Analysis of dihydrofolate reductase and reduced folate carrier gene status in relation to methotrexate resistance in osteosarcoma cells. Ann Oncol 5: 151-160, 2004.

11. De Jonge R, Hooijberg JH, van Zelst BD, et al: Effect of polymorphisms in folate-related genes on in vitro methotrexate sensitivity in pediatric acute lymphoblastic leukemia. Blood 106: 717-720, 2005.

12. Assaraf YG: Molecular basis of antifolate resistance. Cancer Metastasis Rev 26: 153-181, 2007.

13. Goto Y, Yue L, Yokoi A, et al: A novel single-nucleotide polymorphism in the 3'-untranslated region of the human dihydrofolate reductase gene with enhanced expression. Clin Cancer Res 7: 1952-1956, 2001.

14. Dulucq S, St-Onge G, Gagne V, et al: DNA variants in the dihydrofolate reductase gene and outcome in childhood ALL. Blood 111: 3692-3700, 2008.

15. Seguro-popular: Secretaria de Salud/ Seguro Popular, Información disponible en URL http://www.seguro-popular. salud.gob.mx/ (Accessed May, 2009).

16. Reiter A, Schrappe M, Ludwig WD, et al: Chemotherapy in 998 unselected childhood acute lymphoblastic leukemia patients. Results and conclusions of the multicenter trial ALL-BFM 86. Blood 84: 3122-3133, 1994.

17. Smith M, Arthur D, Camitta B, et al: Uniform approach to risk classification and treatment assignment for children with acute lymphoblastic leukemia. J Clin Oncol 14: 18-24, 1996.

18. Merante F, Raha S, Reed JK and Proteau G: The simultaneous isolation of RNA and DNA from tissues and cultured cells. Methods Mol Biol 58: 3-9, 1996.

19. Organista-Nava J, Gómez-Gómez Y, Saavedra-Herrera MV, et al: Polymorphisms of the $\gamma$-glutamyl hydrolase gene and risk of relapse to acute lymphoblastic leukemia in Mexico. Leukemia Res 34: 728-732, 2010.

20. Kooloos WM, Wessels JAM, van der Straaten T, Allaart CF, Huizinga TWJ and Guchelaar HJ: Functional polymorphisms and methotrexate treatment outcome in recent-onset rheumatoid arthritis. Pharmacogenomics 11: 163-175, 2010.

21. Gellekink H, Blom HJ, van der Linden IJ and den Heijer M: Molecular genetic analysis of the human dihydrofolate reductase gene: relation with plasma total homocysteine, serum and red blood cell folate levels. Eur J Hum Genet 15: 103-109, 2007.

22. Mishra PJ, Longo GSA, Menon LG, Abali EE, Humeniuk R, Cole PD, Kamen BA, Banerjee D and Bertino JR: The 829C-T single nucleotide polymorphism in the 30 UTR of the dihydrofolate reductase gene results in methotrexate resistance and is rare among non-Japanese American patients. Proc Amer Assoc Cancer Res 301: 1274, 2006.

23. Parle-McDermott A, Pangilinan F, Mills JL, et al: The 19-bp deletion polymorphism in intron-1 of dihydrofolate reductase (DHFR) may decrease rather than increase risk for spina bifida in the Irish population. Am J Med Genet Part A 143: 1174-1180, 2007.

24. Ng SM, Lin HP, Ariffin WA, Zainab AK, Lam SK and Chan LL: Age, sex, haemoglobin level, and white cell count at diagnosis are important prognostic factors in children with acute lymphoblastic leukemia treated with BFM-type protocol. J Trop Pediatr 46: 338-343, 2000 .

25. Frankel LS, Ochs J, Shuster JJ, et al: Therapeutic trial for infant acute lymphoblastic leukemia: the Pediatric Oncology Group experience (POG 8493). J Pediatr Hematol Oncol 19: 35, 1997.

26. Shuster JJ, Wacker P, Pullen J, et al: Prognostic significance of sex in childhood B-precursor acute lymphoblastic leukemia: a Pediatric Oncology Group Study. J Clin Oncol 16: 2854-2863, 1998.

27. Kim K, Kang SB, Chung HH, Kim JW, Park NH and Song YS: XRCC1 Arginine 194 Tryptophan and GGH-401 Cytosine/ Thymine polymorphisms are associated with response to platinum-based neoadjuvant chemotherapy in cervical cancer. Gynecol Oncol 111: 509-515, 2008. 
28. Dervieux T, Greenstein N and Kremer J: Pharmacogenomic and metabolic biomarkers in the folate pathway and their association with methotrexate effects during dosage escalation in rheumatoid arthritis. Arthritis Rheum 54: 3095-3103, 2006.

29. Chessells JM, Veys P, Kempski H, et al: Long term follow up of relapsed childhood acute lymphoblastic leukaemia. Br J Haematol 123: 396-405, 2003.

30. Chen SH, Yang CP, Hung IJ, Jaing TH, Shih LY and Tsai MH: Clinical features, molecular diagnosis, and treatment outcome of infants with leukemia in Taiwan. Pediatr Blood Cancer 55: 1264-1271, 2010.
31. Daniel-Cravioto A, Gonzalez-Bonilla CR, Mejia-Arangure JM, et al: Genetic rearrangement MLL/AF4 is most frequent in children with acute lymphoblastic leukemias in Mexico City. Leuk Lymphoma 50: 1352-1360, 2009.

32. Bernaldez-Rios R, Ortega-Alvarez MC, Perez-Saldivar ML, Alatoma-Medina NE and del Campo-Martinez M: The age incidence of childhood B-cell precursor acute lymphoblastic leukemia in Mexico City. J Pediatr Hematol/Oncol 30: 199-203, 2008. 